\title{
Fifty years of serving public health: the Association of Schools of Public Health in the European Region moving forward to the next half-century
}

\author{
Jacqueline Müller-Nordhorn • Vesna Bjegovic-Mikanovic • Robert Otok • \\ Katarzyna Czabanowska • Anders Foldspang
}

Received: 21 April 2016/Accepted: 25 April 2016/Published online: 29 April 2016

(c) Swiss School of Public Health (SSPH+) 2016

Half a century of the Association of Schools of Public Health in the European Region (ASPHER) covers only half of the lifespan of some schools of public health in Europe. The London School of Hygiene and Tropical Medicine was founded in 1899, it was followed by such centres as: the Spanish Escuela Nacional de Sanidad in 1924, the Zagreb Stampar School of Public Health in 1927, the Athens School in 1929, the French Ecole National de Santé Publique in 1945, and the Nordic School of Public Health-Nordiska Hälsovårdshögskolan-in 1953 (Foldspang et al. 2016). In 1966, ASPHER was established due to the initiative of the World Health Organization's Office for Europe and its international professional network. The Association's development accelerated over the last half of the twentieth and beginning of the twenty-first century when many more schools and university departments of public health came to existence (Foldspang et al. 2016; Bjegovic-Mikanovic et al.

\section{J. Müller-Nordhorn $(\square)$}

Institute of Public Health, Charité - Universitätsmedizin Berlin, Seestr. 73, 13347 Berlin, Germany

e-mail: jacqueline.mueller-nordhorn@charite.de

\section{Bjegovic-Mikanovic}

School of Public Health and Management, Faculty of Medicine, University of Belgrade, Belgrade, Serbia

R. Otok

ASPHER Office, Brussels, Belgium

\section{K. Czabanowska}

Department of International Health, Faculty of Health, Medicine and Life Sciences, Maastricht University, Maastricht, The Netherlands

\section{A. Foldspang}

Department of Public Health, Aarhus University, Aarhus, Denmark
2014). ASPHER itself played a crucial role in the creation and development of schools in Central and Eastern Europe (CEE) countries during that time (Goodman et al. 2008). Nowadays, ASPHER represents over 110 member schools throughout Europe. A few associate members are located in other parts of the world (Foldspang et al. 2016). New network structures such as the Swiss School of Public Health have been developed with the aim to strengthen public health education, research, and training (Künzli et al. 2015).

It goes without saying that decision-makers, scientists, doctors, nurses, and other health professionals specialising in public health are increasingly working together to improve the health of the population, and ASPHER has joined this movement. Multidisciplinary public health education and training in the European context has undergone a substantial evolution ranging from short specific courses, through post-graduate master of public health studies to the three-cycle Bologna education including bachelor, master and doctorate levels (BjegovicMikanovic et al. 2014).

During ASPHER's lifetime public health evolved from a primarily medically oriented discipline in most countries, with hygiene and basic epidemiology of diseases as the main core disciplines, to an umbrella science and art relying on the multidisciplinarity. In order to improve population health and be able to intervene (cost)-effectively and ethically, expertise in: sociology, anthropology, social psychology, ethics, environmental science, health economics, management, communication and advocacy, advanced statistical and epidemiological and qualitative research methods is needed. The development and evaluation of the complex interventions in disease prevention, health education and health protection also require leadership, strategic planning, implementation and follow-up (Vukovic et al. 2014; Bertoncello et al. 2015). 
As outlined in ASPHER's lists of European core competences (Birt and Foldspang 2011), included in WHO's public health action plan (WHO Europe 2012), a public health professional in the health scene is the natural partner of decision-makers with a political science degree. A health background is no longer compulsory for public health study programme applicants; instead, models for inter- and trans-professional education are becoming increasingly important. ASPHER has continuously sustained this development, which is strongly reflected in its activities over the years. In close collaboration with WHO Europe, ASPHER is a key partner in developing the public health workforce by defining the Essential Public Health Operation No. 7 of WHO Europe (Bjegovic-Mikanovic et al. 2015). The establishment of an educational programme accreditation function represented by the Agency for Public Health Education Accreditation (APHEA), supported by the European Public Health Association (EUPHA), European Health Management Association (EHMA), European Public Health Alliance (EPHA), and EuroHealthNet in 2011, was a landmark (Otok et al. 2011).

In 2014, ASPHER launched its 2016-2020 Strategic Plan (ASPHER 2020), based on five main objectives:

1. Improving the quality of academic programmes and continuing professional development (CPD) for public health.

2. Strengthening the research capacity among all members.

3. Setting up a public health profession for public health services in Europe.

4. Developing the global dimension of education and training for public health.

5. Strengthening governance, management and sustainable development of ASPHER.

Developments based on these objectives do reach far beyond 2020 in the interaction between changing population health challenges, public heath interventions and the development of individual and institutional competences. The shaping of an authorised public health profession, based on its competences and covering the comprehensive dynamics of the discipline (Foldspang 2015) is crucial for the prevention of population health crises.

Most European countries have particular public health services scattered amongst various hosts, many of which are basically medical and not within the realm of public health. Furthermore, principles and methods for the systematic assessment of public health workforce and education and training capacity needs should be developed. Competency-based examination for national and European degrees should be established. ASPHER is embracing all these developments.

Finally, there is an emerging realisation of the vital role of leadership in public health. ASPHER has shown and is showing sustainable leadership in its collaborative efforts to build the strategy and future vision not only for the development of the schools and departments of public health, but also by making public health a fundamental value necessary for the stability and wellbeing of society.

\section{References}

ASPHER 2020: http://aspher.org/repository,5,0,0.html. Accessed 21 Apr 2016

Bertoncello C, Buja A, Silenzi A, Specchia ML, Franchino G, Lazzari A, Baldo V, Ricciardi W, Damiani G (2015) Good governance competencies in public health to train public health physicians. Int J Public Health 60:737-749

Birt C, Foldspang A (2011) European Core Competences for the Public Health Professional (ECCPHP). ASPHER's European Core Competences Programme. Association of Schools of Public Health in the European Region, Brussels

Bjegovic-Mikanovic V, Czabanowska K, Flahault A, Otok R, Shortell S, Wisbaum W, Laaser U (2014) Addressing needs in the public health workforce in Europe. WHO, ASPHER and the European Observatory on Health Systems and Policies, Copenhagen

Bjegovic-Mikanovic V, Foldspang A, Jakubowski E, Müller-Nordhorn J, Otok R, Stjernberg L (2015) Developing the public health workforce. Eurohealth Int Incorp Euro Obs 21:32-35

Europe WHO (2012) The European action plan for strengthening public health capacities and services. World Health Organization, Regional Office for Europe, Copenhagen

Foldspang A (2015) Towards a public health profession: the roles of essential public health operations and lists of competences. Eur J Public Health 25:361-362

Foldspang A, Müller-Nordhorn J, Bjegovic-Mikanovic V, Otok R (eds) (2016) Fifty years of professional public health workforce development. ASPHER's 50th Anniversary Book. Association of Schools of Public Health in the European Region, Brussels

Goodman J, Overall J, Tulchinsky T (2008) Public health workforce capacity building: lessons learned from "Quality Development of Public Health Teaching Programmes in Central and Eastern Europe". Association of Schools of Public Health in the European Region, Brussels

Künzli N, Crivelli L, Sprumont D, Nocera S (2015) Does the Swiss school of public health exist? Int J Public Health 60(8):873-5

Otok R, Levin I, Sitko S, Flahault A (2011) European accreditation of public health education. Public Health Rev 33:30-38

Vukovic D, Bjegovic-Mikanovic Otok R, Czabanowska K, Nikolic Z, Laaser U (2014) Which level of competence and performance is expected? A survey among European employers of public health professionals. Int J Public Health 59(1):15-30 